\title{
高圧水素ガス環境下におけるオーステナイト系ステンレス鋼溶接金属の 水素脆化に及ぼす化学成分および組織の影響*
}

\author{
平田＼cjkstart弘征**, 大村 朋彦**, 浄德 佳奈**, 中村＼cjkstart潤***, 小薄 孝裕**
}

\author{
Effects of Chemical Compositions and Microstructure on Hydrogen Embrittlement of Austenitic \\ Stainless Steel Weld Metal in High Pressure Gaseous Hydrogen Environment*
}

by HIRATA Hiroyuki**, OMURA Tomohiko**, JOTOKU Kana**, NAKAMURA Jun*** and OSUKI Takahiro**

\begin{abstract}
Effect of chemical compositions and microstructures on hydrogen embrittlement of austenitic stainless steel weld metals in high pressure hydrogen gas was surveyed by using the Slow Strain Rate Test.

As a result, hydrogen emblittlement of weld metal was hardly influenced by delta ferrite in weld metal, but by stability of austenite phase, which was estimated by $\mathrm{Md}_{30}$ value or $\mathrm{Ni}$ equivalent. In the weld metal with poor stability of austenite, $\alpha^{\prime}$ martensite was formed near crack induced by SSRT. Additionally, though the crystal structure of $\alpha^{\prime}$ martensite is as same as delta ferrite, susceptibility of hydrogen emblittlement became higher with the increase of $\alpha^{\prime}$ martensite

The mechanism to explain the difference between delta ferrite and $\alpha^{\prime}$ martensite was considered as following. The hardness, which increases the hydrogen embrittlement susceptibility in bcc structure, is higher in $\alpha^{\prime}$ martensite than in delta ferrite. In addition, $\alpha^{\prime}$ martensite might be formed continuously with propagation of crack. Therefore, the effect of $\alpha^{\prime}$ martensite on hydrogen embrittlement could be larger compared with delta ferrite.
\end{abstract}

Key Words: Weld metal, Hydrogen embrittlement, Austenitic stainless steel, Delta ferrite, Martensite

\section{1. は じめに}

水素は宇宙に最も多く存在する元素であり，かつクリー ンなエネルギーであることから, 近い将来, 石油や石炭等の 化石燃料に代わって社会の中核をになうエネルギーとして 期待され，その利用技術である燃料電池の開発が積極的に 進められている. 水素は常温では気体であるため, その取り 扱いは石油を精製したガソリンに代表される液体燃料に比 べて容易ではない，水素を安全に貯蔵・輸送するためには, 液体水素や水素吸蔵合金を使用する方法が知られている が，圧縮水素ガスを活用する方法が最も実用化に近いと考 えられている. 既に, 樹脂系材料を使用した燃料電池車積載 用 $35 \mathrm{MPa}$ 高圧水素タンクの実用化がなされており, 圧力を $70 \mathrm{MPa}$ まで高めた水素タンクの開発も進められている。し かしながら, 将来の水素エネルギー社会の到来に際しては, 水素供給ステーションの整備が必要であり, そこで使用さ れる貯蔵用タンクや輸送用配管に使用する材料について,

\footnotetext{
*受付日 平成25年 8 月26日 受理日 平成25年11月 1 日 平 成19年度春季全国大会で発表

**正 員 新日鐵住金株式会社 Member, Nippon Steel \& Sumitomo Metal Corporation

新日鐵住金株式会社 Nippon Steel \& Sumitomo Metal Corporation
}

低コストかつリサイクル性に優れた金属系材料の適用が検 討されている1).

一方, 金属材料は常温水素ガス環境下で脆化を生じること が知られており 2)，古くから各種金属材料の脆化特性の評価 が体系的に行われている ${ }^{2,3}$. 金属材料の中でも鉄鋼材料は, アルミニウム合金やチタンに比べ，コストならびにリサイク ル性に優れ, 様々な産業分野に使用されている.中でも fcc 構 造を有するオーステナイト系ステンレス鋼はbcc 構造を有 する金属材料に比べて脆化を起こし難いといわれており ${ }^{3)}$, 高圧水素ガス環境下での脆化特性について種々検討がなさ れている4-7. 例えば, SUS316L ステンレス鋼では, 常温から $85^{\circ} \mathrm{C}$ まで脆化しないことが報告されている4).一方では, 常温 でオーステナイト組織を有する各種ステンレス鋼の水素脆 化感受性を比較し，同じ316系ステンレス鋼においても化学 成分により水素脆化感受性に差が有ることが指摘されてい る。.

ところで, 鉄鋼材料の構造化には溶接による組み立てが必 要不可欠と考えられる. 加工, 熱処理によって調質がなされ た母材に対し，溶接金属は凝固組織ままで使用されるのが一 般的である。特に，オーステナイト系ステンレス鋼用溶接材 料では，溶接高温割れ感受性を低減させるため，室温で bcc 構造を有する $\delta$ エライトを数\%含む凝固組織となるよう 成分調整がなされている場合が多い89.オーステナイト系ス テンレス鋼溶接金属の水素脆化感受性に及ぼす溶接金属中 
Table 1 Chemical compositions of materials used (mass $\%$ )

\begin{tabular}{|c|c|c|c|c|c|c|c|c|c|c|c|}
\hline Heat & $\mathrm{C}$ & $\mathrm{Si}$ & $\mathrm{Mn}$ & $\mathrm{P}$ & $\mathrm{S}$ & $\mathrm{Ni}$ & $\mathrm{Cr}$ & Mo & $\mathrm{N}$ & $\mathrm{Ni}_{\mathrm{eq}}$ & $\operatorname{Md}_{30}\left({ }^{\circ} \mathrm{C}\right)$ \\
\hline $308 \mathrm{~A}$ & 0.018 & 0.46 & 1.44 & 0.004 & 0.001 & 11.0 & 18.7 & \begin{tabular}{|l|}
0.01 \\
\end{tabular} & 0.0048 & 25.0 & 25.66 \\
\hline $308 \mathrm{~B}$ & 0.018 & 0.50 & 1.45 & 0.003 & 0.001 & 11.0 & 20.0 & \begin{tabular}{|l|}
0.01 \\
\end{tabular} & 0.0110 & 26.0 & 4.06 \\
\hline $308 \mathrm{C}$ & 0.019 & 0.47 & 1.44 & 0.003 & 0.001 & 10.3 & 19.4 & 0.01 & 0.0061 & 24.9 & 21.08 \\
\hline $308 \mathrm{D}$ & 0.018 & 0.49 & 1.46 & 0.004 & 0.001 & 11.7 & 18.5 & 0.01 & 0.0050 & 25.7 & 20.81 \\
\hline $308 \mathrm{E}$ & 0.019 & 0.50 & 1.43 & 0.003 & 0.001 & 9.1 & 19.4 & 0.01 & 0120 & 3.6 & 0.03 \\
\hline $316 \mathrm{~A}$ & 0.018 & 0.50 & 1.49 & 0.002 & 0. & 13.8 & 18.5 & 1 & 56 & 30.2 & .06 \\
\hline $316 \mathrm{~B}$ & 0.018 & 0.52 & 1.45 & 1 & 0. & 14.0 & 19.7 & 53 & 0 & 31.2 & .26 \\
\hline $316 \mathrm{C}$ & 0.019 & 0.50 & 1.46 & 0.002 & 0.001 & 12.0 & 18.4 & 2.52 & 0.0077 & 28.4 & -29.01 \\
\hline $316 \mathrm{D}$ & 0.018 & 0.49 & 1.49 & 0.002 & 0.001 & 13.4 & 17.5 & 2.52 & 0.0060 & 29.2 & -28.35 \\
\hline $316 \mathrm{E}$ & 0.018 & 0.52 & 1.45 & 0.001 & 0.001 & 11.0 & 18.5 & 2.52 & 0.0047 & 27.4 & -18.53 \\
\hline
\end{tabular}

に含まれる $\delta$ フェライトの影響についても古くから報告がな されており，例えば，J.A. Brooks らは10\%程度までの $\delta$ フ ライトは水素脆化感受性にほとんど影響を及ぼさないとし ている9. 一方, M. I. Luppo らは, $30 \%$ 程度まで $\delta$ フェライト 量を変化させた溶接金属の水素脆化感受性について検討し, 特に $\delta$ フライト量が多い場合に水素脆化が顕著となるこ とを示している ${ }^{10)}$ ここのように, オーステナイト系溶接金属 中の $\delta$ フライトの影響については統一した見解が得られ ておらず, 特に, 高圧水素ガス環境下における脆化挙動の解 明は未だ十分ではない.

本報では, 実用の観点から重要であると考えられる高圧水 素ガス環境下におけるオーステナイト系ステンレス鋼溶接 金属の脆化挙動を明らかにすることを目的に, 水素脆化感受 性に及ぼす化学成分ならびに組織の影響について検討した.

\section{2. 供試材料および実験方法}

\section{1 供試材料}

Table 1 に示す SUS308L 鋼ならびに SUS316L 鋼をベース に $\mathrm{Cr}, \mathrm{Ni}$ 量を変化させた厚さ $10 \mathrm{~mm}$ の鋼板を供試鋼板とし て用いた，材料は, 実験室にて $17 \mathrm{~kg}$ 規模で真空溶解し, 鍛 造, 圧延後, $1323 \mathrm{~K} \times 1.8 \mathrm{ks}$ の固溶化熱処理を行うことにより 作製した. Table 1 にはそれぞれ (1) 式で求められるオーステ ナイトの相安定性に対する合金元素の影響を表す $\mathrm{Ni}$ 当量 ${ }^{11}$ ならびに (2) 式で求められる $30 \%$ の加工によりオーステナ イトから $50 \%$ のマルテンサイトが生成する温度 $\left({ }^{\circ} \mathrm{C}\right)$ を表す $\mathrm{Md}_{30}$ 值 ${ }^{12)}$ を併せて示す.

$\mathrm{Ni}_{\text {cq }}=\mathrm{Ni}+0.65 \mathrm{Cr}+0.98 \mathrm{Mo}+1.05 \mathrm{Mn}+0.35 \mathrm{Si}+12.6 \mathrm{C}$

$\mathrm{Md}_{30}=413-462(\mathrm{C}+\mathrm{N})-9.2 \mathrm{Si}-8.1 \mathrm{Mn}-13.7 \mathrm{Cr}-9.5 \mathrm{Ni}-18.5 \mathrm{Mo}$

\section{2 実験方法}

供試鋼板上に深さ $2 \mathrm{~mm}$, 角度 $90^{\circ}$ の $\mathrm{V}$ 型溝を機械加工に より設け,プラズマ溶接により溶接材料を使用せずにビード オンプレート溶接した. 尚, 入熱は約 $1.5 \mathrm{~kJ} / \mathrm{mm}$ とし, シール

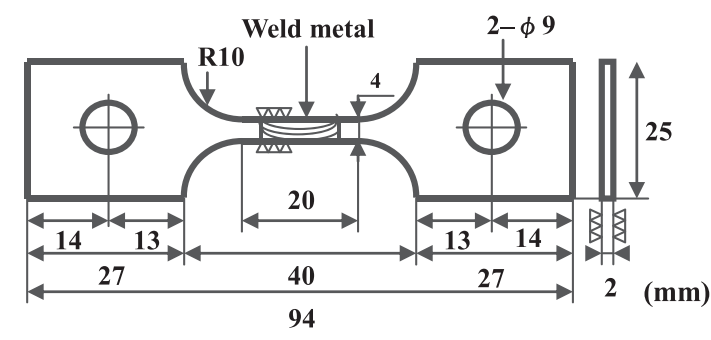

Fig. 1 Schematic illustration of test specimen for SSRT

ドガス，センターガスとも純アルゴンを使用した。

得られた溶接継手から溶接金属を中央部に持つ横断面試 験片を採取し, 研磨, 腐食により溶接金属のミクロ組織を現 出し, 光学顕微鏡により組織観察を行うとともに, 溶接金属 中の $\delta$ フライト率を画像解析により求めた. 得られた溶接 継手から Fig. 1 に示す溶接金属を平行部の中央に有する板 状引張試験片を機械加工により採取し, 低ひずみ速度引張試 験（Slow Strain Rate Test, SSRT）に供した. 試験は常温で大気 ならびに $45 \mathrm{MPa}$ の水素ガス環境下で実施し，ひずみ速度は $3 \times 10^{-6}\left(\mathrm{~s}^{-1}\right)$ とした.

加えて, SSRT 試験後の溶接金属のミクロ組織も同様に現 出し, 組織観察を行うとともに, 溶接金属中の bcc 構造を有 する組織の割合を X 線回折法により測定した。さらには, 破 面の走査型電子顕微鏡 (Scanning Electron Microscope, SEM) 観察を行った.

\section{3. 実 験 結 果}

\section{1 溶接金属のミクロ組織}

溶接金属のミクロ組織の観察例を Fig. 2 に示す. 化学成分 に係わらず，いずれの溶接金属にもデンドライト境界に母相 と異なる相が観察された。さらに，その生成量には化学成分 により差異が認められた. Table 2 は母相ならびにデンドライ 卜境界に認められた相中の $\mathrm{Cr}, \mathrm{Ni}$ および Mo 量を電子線マ イクロアナライザー (Electron-Probe Micro-Analyzer, EPMA) 




Fig. 2 Microstructures of weld metals

Table 2 Results of EPMA analysis (mass\%)

\begin{tabular}{|c|c|c|c|c|}
\hline Heat & Analysis location & $\mathrm{Ni}$ & $\mathrm{Cr}$ & $\mathrm{Mo}$ \\
\hline \multirow{2}{*}{$308 \mathrm{~A}$} & Matrix & 9.75 & 17.73 & - \\
\cline { 2 - 5 } & Phase observed at dendrite boundary & 5.14 & 22.69 & - \\
\hline \multirow{2}{*}{$308 \mathrm{~B}$} & Matrix & 13.46 & 19.86 & - \\
\cline { 2 - 5 } & Phase observed at dendrite boundary & 7.59 & 25.38 & - \\
\hline \multirow{2}{*}{$308 \mathrm{C}$} & Matrix & 11.61 & 19.11 & - \\
\cline { 2 - 5 } & Phase observed at dendrite boundary & 7.66 & 23.01 & - \\
\hline \multirow{2}{*}{ 308D } & Matrix & 12.74 & 18.29 & - \\
\cline { 2 - 5 } & Phase observed at dendrite boundary & 9.11 & 22.32 & - \\
\hline \multirow{2}{*}{$308 \mathrm{E}$} & Matrix & 9.43 & 19.31 & - \\
\cline { 2 - 5 } & Phase observed at dendrite boundary & 8.78 & 20.34 & - \\
\hline \multirow{2}{*}{$316 \mathrm{~A}$} & Matrix & 15.24 & 18.45 & 1.92 \\
\cline { 2 - 5 } & Phase observed at dendrite boundary & 10.56 & 24.59 & 5.37 \\
\hline \multirow{2}{*}{$316 \mathrm{~B}$} & Matrix & 15.04 & 20.29 & 2.43 \\
\cline { 2 - 5 } & Phase observed at dendrite boundary & 9.78 & 24.38 & 4.15 \\
\hline \multirow{2}{*}{ 316C } & Matrix & 13.23 & 18.24 & 2.18 \\
\cline { 2 - 5 } & Phase observed at dendrite boundary & 8.71 & 22.23 & 3.4 \\
\hline \multirow{2}{*}{ 316E } & Matrix & 11.86 & 18.59 & 2.53 \\
\cline { 2 - 5 } & Phase observed at dendrite boundary & 10.55 & 20.62 & 3.09 \\
\hline
\end{tabular}

により定量分析した結果を示す.デンドライト境界に認めら れた相は母相に比べて Cr, Mo が濃化し, Ni が貧化していた. このことから, 凝固時に生成した $\delta$ フェライトであると判断 された ${ }^{133}$.

\section{2 溶接金属の水素脆化感受性}

SSRT における大気中での破断絞りに対する高圧水素ガス 環境下での破断絞りの比（以下，相対破断絞り）と溶接金属 中の $\delta$ フェライト率の関係を Fig. 3 に示す. $\delta$ フェライト率 が増加した場合, SUS316L 系溶接金属では相対破断絞りの 低下はほとんど認められなかったのに対し, SUS308L 系溶 接金属では僅かではあるが相対破断絞りが低下した。さら に, 同等の $\delta$ フェライトを含む場合, SUS316L 系溶接金属に 比して, SUS308 系溶接金属は相対破断絞りが小さかった.

Fig. 4 は $\delta$ フェライト率が約 10\%でほほ等しい SUS308L 系 溶接金属ならびに SUS316L 系溶接金属の高圧水素ガス環境

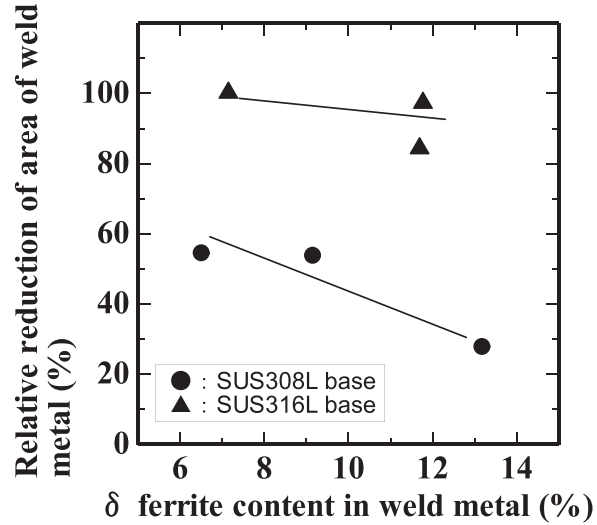

Fig. 3 Effect of $\delta$ ferrite fraction in weld metal on relative reduction of area evaluated by SSRT

下での SSRT 後の破面観察結果を示す.また, Fig. 5 は $\delta$ フェ ライト率が約 7\% と等しいSUS308L およびSUS316L 系溶 接金属のSSRT 試験破面近傍の断面ミク口観察結果を示す. 破面観察の結果, 相対破断絞りの低下がほとんど認められな かった SUS316L 系溶接金属は十分な変形を伴い破断し，全 面にわたりディンプル状の破面を呈していた. 加えて, 断面 観察の結果, 主き裂は $\delta$ フェライト中のみを選択的に伝播す るのではなく,オーステナイト中をも貫通しており，二次き 裂の発生はほとんど認められなかった。 それに対し, 同程度 の $\delta$ フェライトを含むにもかかわらず, 相対破断絞りの低下 が顕著であった SUS308L 系溶接金属では, 破面観察の結果, ほとんど変形を伴わない擬へき開状の破面が観察された.し かしながら, 断面観察の結果, 多くの二次き裂の発生が観察 されたものの, き裂は $\delta$ フライトおよびオーステナイト中 を貫通して伝播しており，SUS316L 系溶接金属との差異は 明暸に認められなかった. Fig. 6 には相対破断絞りを (1) 式揖 よび (2) 式に示した $\mathrm{Ni}$ 当量ならびに $\mathrm{Md}_{30}$ 值で整理した結果 を示す.オーステナイトの安定性を示すこれらのパラメー夕 一と相対破断絞りの間には良い相関が認められた。そして, 


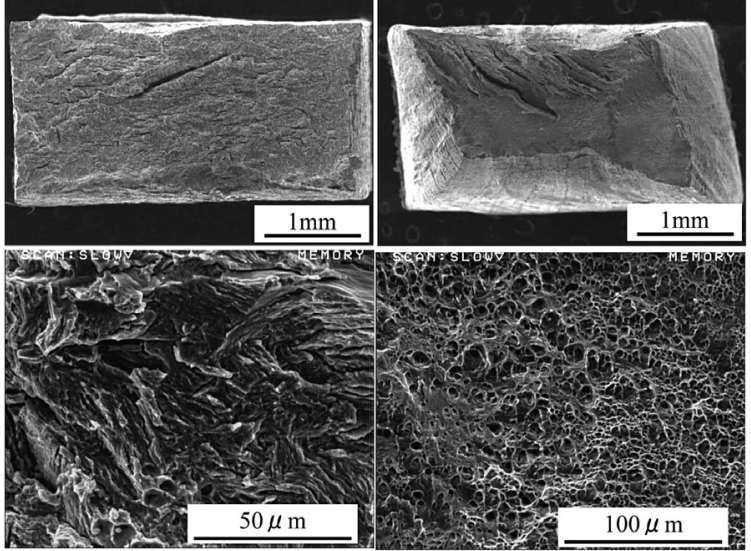

(a) Heat: $308 \mathrm{C}$ [ $\delta$ ferrite fraction : $9.8 \%$ ] [ $\delta$ ferrite fraction : $11.8 \%$ ]

Fig. 4 SEM images of fractured surface of test specimens after SSRT in high pressure $\mathrm{H}_{2}$ gas
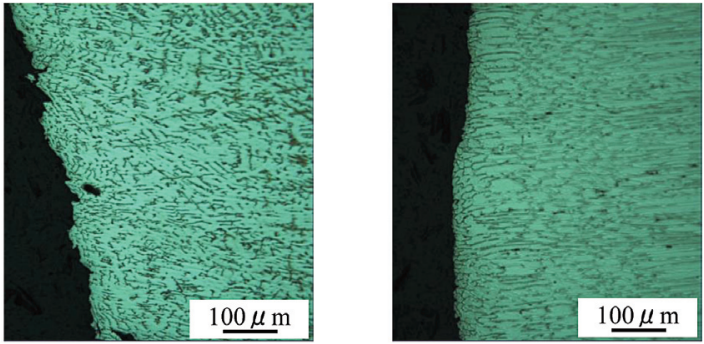

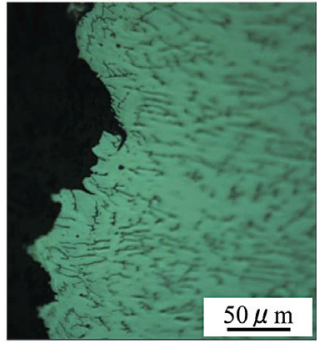

(a) Heat: $308 \mathrm{~A}$

[ $\delta$ ferrite fraction : $6.5 \%$ ]

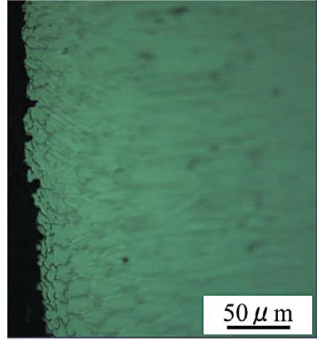

(b) Heat: $316 \mathrm{~A}$

[ $\delta$ ferrite fraction : $7.1 \%]$
Fig. 5 Optical microstructures of cross section near fractured surface of test specimens after SSRT in high pressure $\mathrm{H}_{2}$ gas

$\mathrm{Ni}$ 当量が $28 \%$ を超える，もしくは $\mathrm{Md}_{30}$ 值が $-30^{\circ} \mathrm{C}$ を下回る と高圧水素環境下で破断絞り值はほとんど低下しなかった.

これらの結果は, 本検討の範囲では, 水素脆化感受性は凝 固時の溶接金属に含まれる $\delta$ フェライト量よりも，加工時 のオーステナイトの安定性の影響を受けることを強く示唆 する結果であり，ベース組成がそれに影響を及ぼすと考え られた。

SUS308L 系溶接金属を高圧水素ガス環境下で SSRT によ り破断させた試験片の破面近傍のマイクロビッカース試験に よる硬さ測定結果を Fig. 7 に示す。凝固ままの溶接金属中に 存在した $\delta$ フライトは，硬さが $230 \mathrm{HV}$ 程度であったのに 対し，その周囲の基質は硬さが約 $280 \mathrm{HV}$ と高かった. Fig. 8 は，SSRT 後の溶接金属に含まれる bcc 構造を有する相の割



(a) $\mathrm{Ni}$ equivalent

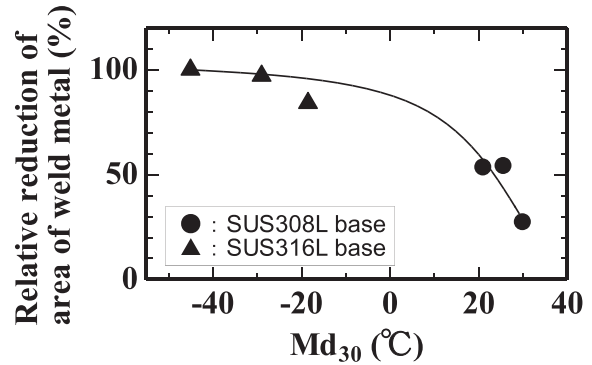

(b) $\mathrm{Md}_{30}$ value

Fig. 6 Effects of $\mathrm{Ni}$ equivalent and $\mathrm{Md}_{30}$ value of weld metal on relative reduction of area evaluated by SSRT



Fig. 7 Vickers hardness value measured at locations near fractured surface of test specimens after SSRT in high pressure $\mathrm{H}_{2}$ gas

合を X 線回折法により求め, (2) 式に示した $\mathrm{Md}_{30}$ 值で整理し た結果を示す。図中には Fig. 3 に示した SSRT 試験前の凝固 ままの溶接金属に含まれた $\delta$ フライト率を併せて示す.

尚, SSRT 試験前の溶接金属の一部について X 線回折法にに より $\delta$ フェライト率を測定した結果, 画像解析により導出し た結果と概ね対応していた。

$\mathrm{Md}_{30}$ 值が小さい場合, SSRT 前後の $\delta$ フェライト率と bcc 相率の間に差異は認められなかった。しかしながら, $\mathrm{Md}_{30}$ 值 が大きくなると，SSRT 前の $\delta$ フライト率に比べて SSRT 後の bcc 相率が多くなり，その増加幅が大きくなった.

中村ら ${ }^{14)}$ は準安定オーステナイトステンレスである SUS304 鋼の高圧水素環境下での疲労き裂先端で $\alpha^{\prime}$-マルテ ンサイトが生成することを示している，さらに，C量が少な い場合にはマルテンサイトはbct 構造ではなく, bcc 構造を 有することが知られている ${ }^{15)}$. これらの報告ならびに Fig. 8 に示した結果を併せて考えると SSRT 前後における bcc 相 率と $\delta$ フライト率の差は, 歪により破断部近傍に生成した 


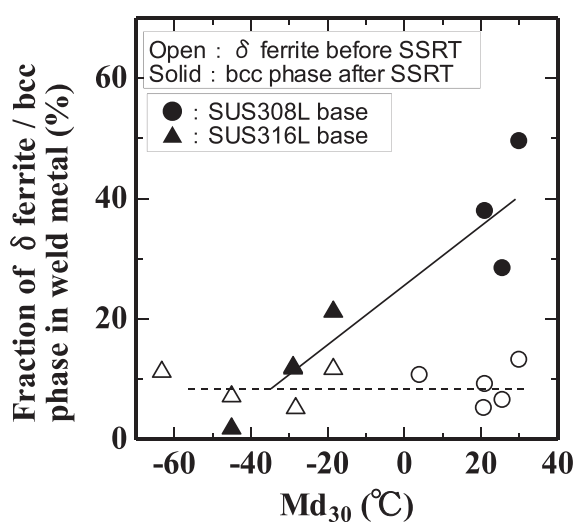

Fig. 8 Effect of $\mathrm{Md}_{30}$ value on fraction of bcc / $\delta$ ferrite phase before and after SSRT

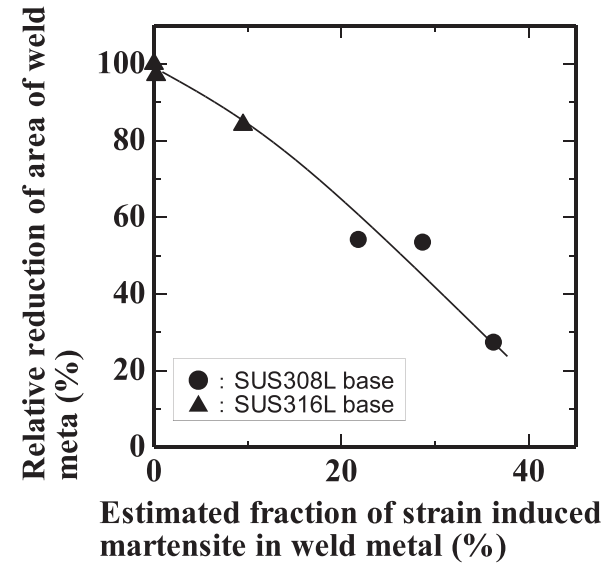

Fig. 9 Relationship between estimated fraction of strain induced martensite in weld metal and relative reduction of area evaluated by SSRT

$\alpha^{\prime}$-マルテンサイトによると判断される. 尚, 加工により誘起 されるマルテンサイトには $\alpha^{\prime}$-マルテンサイト以外に hcp 構 造を有する $\varepsilon$-マルテンサイトが生成する ${ }^{15)} と$ ぞ知られて いるが, 破断部近傍からのX 線回折試験の結果からは, その 存在を示すピークは認められなかった。

そこで, SSRT 前後に扔ける bcc 相率と $\delta$ フェライト率の 差を $\alpha^{\prime}$-マルテンサイト率と定義し, SSRTに打ける相対破断 絞りとの関係を整理した. 結果を Fig. 9 に示す. 尚, SSRT 前 後における bcc 相率と $\delta$ フララト率の差が負となったも のについては， $\alpha^{\prime}$-マルテンサイトが生成しなかったものと 判断し， $\alpha^{\prime}-$ マルテンサイト率が 0 としてプロットした。 $\alpha^{\prime}$ マルテンサイト率と相対破断絞りには相関が認められ， $\alpha^{\prime}-$ マルテンサイト率が大きいほど高圧水素ガス環境下での脆 化が顕著となることが明らかとなった。

以上より, 溶接金属の水素脆化感受性は, $\alpha^{\prime}$-マルテンサイ 卜の影響を強く受けることが明らかとなった。ささらに, $\alpha^{\prime}$-マ ルテンサイト比べると, $\delta$ フェライトの影響は小さいことが 併せて明らかとなった。そして, SUS308L 系溶接金属は SUS316L 系溶接金属に比べてオーステナイトの安定性に劣 るため, 常温での加工により， $\alpha^{\prime}-$ マルテンサイトが生成し,
水素脆化感受性が高くなるものと判断された.

\section{4. 溶接金属の水素脆化感受性に及ぼす組織の 影響に関する考察}

上述の通り, 本検討の範囲では溶接金属の水素脆化感受性 に対する凝固時に生成した $\delta$ フェライトの影響は小さかっ た。年れに対し， $\delta$ フェライトと同じく bcc 構造を有するに も倸わらず， $\alpha^{\prime}$-マルテンサイト相が生成した場合, 水素脆化 感受性が高くなった。この理由は以下のように考えられる。

即ち, bcc 構造を有するフェライト鋼において水素脆化感 受性はその硬さに依存し, 硬さの高い材料ほど水素脆化感受 性が高いことが知られている ${ }^{16,177}$. Fig. 7 に示したように SSRT にて破断した試験片の破断部近傍のミクロ組織観察な らびに硬さ測定の結果, 加工により生成した $\alpha$ '-マルテンサイ 卜と考えられる組織は $\delta$ フライトに比べて硬さが高かっ た。さらに，今後の実験的検証は必要であるが，脆化の原因 となる水素はフェライトに比ベオーステナイトにより多く 固溶する》ことから, 水素を固溶したオーステナイトが加工に より変態して生じる $\alpha^{\prime}$-マルテンサイト中には，平衡状態に おけるフェライトの水素固溶限以上の過飽和の水素を固溶 していると推察される。 そのため， $\alpha$-マルテンサイトは硬い 組織であること，ならびにより多くの水素を吸蔵しているこ とに起因し, 同じ bcc 構造を有するにも係わらず, $\delta$ フェライ 卜よりも高い水素脆化感受性を有したものと推察される.

加えて, 溶接金属中に分散して存在する $\delta$ フェライトとは 異なり， $\alpha^{\prime}$-マルテンサイトはき裂が発生し,オーステナイト 中を進展する際, 歪集中が生じることによりき裂先端部に連 続的に生成すると考えられる。 その結果，溶接金属の水素脆 化感受性には $\alpha^{\prime}$-マルテンサイトの影響が支配的であり，そ の生成により顕著な脆化を示すのに対し， $\delta$ フェライトの影 響は認められなかったものと考えられる。

ところで，き裂先端部に $\alpha^{\prime}$-マルテンサイトが生成すると 考えた場合，き裂先端には，常にマルテンサイトが存在する こととなり, Fig. 9 に示した平均的な $\alpha^{\prime}$-マルテンサイト率の 増加による水素脆化感受性の上昇の説明が困難となる.この 理由は, 次のように理解される。加工により生成する $\alpha^{\prime}$-マル テンサイトの生成量は歪量および加工温度に依存すること が示されている5).この結果は, 試験温度が同じ場合, $\mathrm{Md}_{30}$ 值 が高いオーステナイト相ほど小さな歪で $\alpha$ '-マルテンサイト 変態することを示唆すると言える。 そのため, $\mathrm{Md}_{30}$ 值が高い 溶接金属ほどき裂先端において小さな歪で $\alpha^{\prime}$-マルテンサイ 卜を生成し，脆化を生じさせるため, 溶接金属の水素脆化感 受性は破断後の平均的な $\alpha^{\prime}$-マルテンサイト率の増加ととも に高まったものと考えられる。

\section{5. まと め}

1）本検討の化学成分範囲においては，溶接金属の $\delta$ フェラ 
イトが水素脆化感受性に及ぼす影響は小さい。

2）水素脆化感受性の高い溶接金属では, SSRTによる歪誘起 により $\alpha^{\prime}$-マルテンサイトが生成した。 $\alpha^{\prime}$-マルテンサイ 卜率と溶接金属の水素脆化感受性には相関があり，その 生成量の増加に従い, 水素脆化感受性が増大する.

3）水素脆化感受性に対する $\alpha^{\prime}-$-マルテンサイトの与える影 響が $\delta$ フェイトに比べて顕著であった理由は, $\alpha^{\prime}-$ マル テンサイトが $\delta$ フライトに比して，治金的により水素 脆化感受性が高いことに加え, き裂先端の歪集中により 連続的に生成されることに起因すると考察された。

尚, 本研究は新エネルギー・産業技術総合開発機構 （NEDO）からの委託研究「水素社会構築共通基盤整備事業」 にて実施した内容を一部含む。

\section{参 考 文 献}

1) T. Yamada and H. Kobayashi: 水素ステーション設備に使用する 材料の選定基準, Journal of the Institution for Safety of High Pressure Gas Engineering, 49-10 (2012), 29-37. (in Japanese)

2) H. R. Gray: Hydrogen Embrittlement Testing, ASTM STP 543, (1974), 133.

3) R. P. Jewett: Hydrogen Environment Embrittlement of Metals, NASA contractor report 2163,(1973).

4) T. Omura, K. Kobayashi, M. Miyahara and T. Kudo: Hydrogen Embrittlement Properties of Stainless Steels in High Pressure Gaseous Hydrogen Environment, Zairyo-to Kankyo, 55-4 (2006), 139-145. (in Japanese)

5) S. Fukuyama, L. Zhang, M. Wen and K. Yokogawa: Tensile Properties of SUS304 Stainless Steel in High Pressure Hydrogen at Room Temperature, Journal of the Japan Institute of Metals, 67-4 (2003), 157160. (in Japanese)
6) S. Fukuyama, D. Sun, L. Zhang, M. Wen and K. Yokogawa: Effect of Temperature on Hydrogen Environment Embrittlement of Type 316 Series Austenitic Stainless Steels at Low Temperatures, Journal of the Japan Institute of Metals, 67-9 (2003), 456-459. (in Japanese)

7) S. Fukuyama, L. Zhang and K. Yokogawa: Development of Materials Testing Equipment in High Pressure Hydrogen and Hydrogen Environment Embrittlement of Austenitic Stainless Steels, Journal of the Japan Institute of Metals, 68-2 (2004), 62-65. (in Japanese)

8) S. Ando, Y. Kikuta and Y. Kimura: 現代溶接技術体系 5, Sanpo Syuppan (1980), 51-56. (in Japanese)

9) J. A. Brooks and A. J. West: Hydrogen Induced Ductility Losses in Austenitic Stainless Steel Weld, Metall. Trans. A, 12A-2 (1981), 213-223.

10) M. I. Luppo, A. Hazarabdian and J. Ovejero-Garcia: Effects of delta ferrite on hydrogen embrittlement of austenitic stainless steel welds, Corrosion Science, 41 (1999), 87-103.

11) T. Hirayama and M. Ogirima: Influence of Chemical Composition on Martensitic Transformation in Fe-Cr-Ni Stainless Steel, Journal of the Japan Institute of Metals, 34-5 (1970), 507-510. (in Japanese)

12) Edited by M. Hasegawa: ステンレス鋼便覽, Nikkan Kogyo Shinbunsya (1974), 60.

13) K. Nishimoto, S. Natsume, K. Ogawa and O. Matsumoto: 溶接接合選 書11 ステンレス鋼の溶接, Sanpo Syuppan (2001), 79-82. (in Japanese)

14) J. Nakamura, M. Miyahara, T, Omura, H. Semba and M. Wakita: Fatigue Properties and Degradation Mechanism for Stainless and High Strength Steels in High Pressure Gaseous Hydrogen Environment, Journal of the Society of Materials Science, 60-12 (2011), 1123-1129. (in Japanese)

15) Z. Nishiyama: マルテンサイト変態 基本編, Maruzen (1971), 16, 197. (in Japanese)

16) S. Hinotani, F. Terasaki and K. Takahashi: Hydrogen Embrittlement of High Strength Steels in High Pressure HydrogenGas at Ambient Temparature, Tetsu-to-Hagane, 64-7 (1978), 899-905. (in Japanese)

17) T. Kushida: 東京大学学位請求論文. (in Japanese) 